東北家畜臨床研報 No.11，40～43（1988）

<子 報〉

\title{
甚急性・急性乳房炎の菌種別薬剤感受性と 初診時の臨床症状について
}

\author{
天野靖永・小林和夫・吉田信次 - 角金俊一 \\ 安孫子治・高村定男 - 新田竹重 ${ }^{2}$ \\ 青森県農業共済組合連合会 東部家畜診療所
}

\begin{abstract}
要 約 甚急性および急性乳房炎に対する抗生物質と治療法の選択を的確に行うために、起因菌の薬 剂感受性並らびに初診時における臨床症状について検討した。甚急性・急性乳房炎において、グラム陽 性菌ではほとんどぺニシリン耐性株がみられず、慢性のそれとは大きく異なっていた。また、グラム陽 性菌はクロラムフェニコールに100\%感受性を示した。甚急性・急性乳房炎の50症例をグラム陽性菌（30 例）とグラム陰性菌（26例）に分類し、各々の初診時における臨床症状の差異について検討した。その 結果、グラム陰性菌例では食欲廃絶、元気沈衰、乳房疼痛、乳汁の水様化および乳汁塩素濃度の上昇等 の出現率が他に比べて著明な高値を示した。これらの所見は、地域差を考虑したとしてむ、臨地におけ る治療法の選択に有益であると考えられる。
\end{abstract}

甚急性・急性乳房炎では、一刻も早い起因菌の同定と 薬剂感受性テストが要求される。また、初診時に選択寸 る抗生物質は、多くの場合、これらの検查結果を待たず に投与されている。しかし、この初期治療の良否は、乳 房炎の予後に大きな影響をおよぼすと考えられる。然る に、初診時の臨床症状から起因菌の類別および抗生物質 に対寸る感受性が推測できれば、その治療成績は著しく 向上するものと推測される。

著者らは、急性経過を示す乳房炎の初診時の病徴から 病原菌の類別と感受性が推定できる可能性について、初 診時の乳汁中における起因菌別の抗生物質感受性と臨床 症状との関連性から検討した。

\section{材料と方法}

Amano, Y., Kobayashi, K., Yoshida, S., Tsunogane, S., Abiko, O., Takamura, S., and Nitta, T. (Tobu Veterinary Clinic, Aomori Prefectural Federation of Agricurtural Mutural Aid Association)

In vitro sensitivity of bacteria to antibiotics and clinical symptoms at the initial exmination in peracute or acute mastitis of dairy cows.

Tohoku J. Vet. Clin., No.11, 40-43 (1988)

a ） $\mathbf{T} 039-27$ 青森県上北郡天間林村大字天問館字道 上 $54-43$

\section{1. 分離菌の同定と薬剂感受性試験}

当該診療所管内で、1987年 4 月から1988年 5 月までの 間に発生したホルスタイン種における甚急性・急性乳房 炎の起因菌69株、並びに対照としての慢性乳房炎由来菌 117 株を用いて抗生物質の感受性試験を実施した。病型の 分類は、家畜共済における特殊病傷の「診療指針」に上 ったものであるが、慢性症から急性症へ転化したものや、 严急性、潜在性乳房炎は除外した。分離細菌の同定は安 里 ${ }^{21}$ の方法に従った。抗生物質の感受性試験は、センシ ・ディスク（BBL)を用いた濃度法によって行った。供 試した抗生物質の種類は、ペニシリン ( PC)、アンピシリ

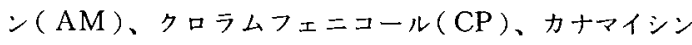

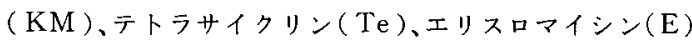
の 6 種類である。

\section{2. 初診時の臨床症状の観察と判別診断}

甚急性をたは急性の乳房炎に椎患した96頭の牛の初診 時における臨床症状としては、次の11項目を観察した

（表 1）。また、乳汁の性状は表 2 に示寸判定基準に準 じて判別した。さらに、1988年5月から8月までに発生 した甚急性・急性乳房炎40例については初診時に判別診 断を行った。 


\section{1. 薬剒感受性試験の成樍}

甚急性・急性乳房炎に䍜患した供試牛から分離された 菌種並びにそれらの各抗生物質感受性菌の割合を表 $3 に$ 示した。Staphylococcus aureus $の$ 甚急性・急性例 13 株では、KM を除く他の抗生物質に感受性を示したが、 慢性例27株では一般に感受性が低く、特に PCに対する 感受性菌の割合は59.3\%であった。コアグラーゼ陰性ブ ドゥ球菌 (CNS) $)$ 甚急性·急性例12株は、S. aureusとは

\section{表 1 . 臨床検査の項目}

\begin{tabular}{|c|c|}
\hline 全身症状 & $\begin{array}{ll}\text { 体 } & \text { 温 }{ }^{\mathrm{C}} \\
\text { 心 } & \text { 拍 } \\
\text { 数 } / \text { 分 } \\
\text { 食 } & \text { 欲 (廃絶の有無) } \\
\text { 元気 沈 衰 }\end{array}$ \\
\hline 局所症 状 & $\begin{array}{l}\text { 乳房 腫 脹 } \\
\text { 乳房 硬 結 } \\
\text { 乳房 疼痛 } \\
\text { 乳房 熱 感 }\end{array}$ \\
\hline 乳汁の性状 & $\begin{array}{l}\text { 乳汁水様化 } \\
\text { 乳汁塩素濃度の上昇 } \\
\text { ブ (大または小) }\end{array}$ \\
\hline
\end{tabular}

表 2. 乳汁性状の判定規準

\begin{tabular}{|c|c|c|}
\hline & 水様化 & 十著しい水様化, 漿液化 \\
\hline & 塩素濃度 & $\begin{array}{r}\rightarrow \text { Hayden の変法により测定 } \\
200 \mathrm{mg} / \mathrm{d} l \text { 以上を呈したもの }\end{array}$ \\
\hline ブ & 大 & 一多量のブッ及び大きなブッ \\
\hline
\end{tabular}

ぼ同様の感受性であった。しかし、慢性例40株ではPC に対して $27.5 \%$ だけであり、S. aureus と比較して䫟著 に P C 酎性菌の出現が増加していた。Streptcoccusは、 甚急性・急性の13株ではP CやAMに対し $92.3 \%$ 、C P やEに対しては100\%であり、感受性菌の割合は高值を 示した。他方、慢性例ではP Cに対して70.6\%が感受性 を示すだけであった。また、KMに対する感受性はいず れの菌群でも著しい低值であった。E. coli の甚急性・急 性例16株および慢性例 5 株では、C Pには $100 \%$ であっ たが、他は低値を示し、P Cには $0 \%$ あったた Klebsi ella の甚急性・急性例15株の感受性は C P 100\%、K M 86 . 7\%であったが、慢性例11株ではC P 100\%交したほか、 K Mが45.5\%を示しただけであった。

\section{2. 初診時の臨床症状と判別診断}

11項目の臨床症状について、グラム陽性菌（30例）と グラム陰性菌（26例）に分けて各々の平均值および出現 率を求めたところ、表 4 および図 1 に示す成績を得た。 その結果、食欲廃絶、元気沈衰、乳房疼痛、乳汁の水様 化、乳汁塩素濃度の 5 項目では、グラム陰性菌の出現率 が有意 $(\mathrm{p}<0.01)$ に高く、またブッ大ではグラム陽性 菌の出現率が有意 $(\mathrm{p}<0.01)$ な高值を示した。

以上の成績から、前述の11項目の臨床症状を含めて図 2 に示すような乳房炎細菌検查依賴カードを作成した。 次いで、こ札を40例の甚急性・急性乳房炎に䍜患した牛 の初診時に応用した。その結果、獣医師により当該カー ドに記入された所見から推定した起因菌種は34例が適中 し、適中率 (診断率) が85\%であった。

表 3 ・甚急性・急性㧍よび慢性乳房炎起因菌における薬剤感受性

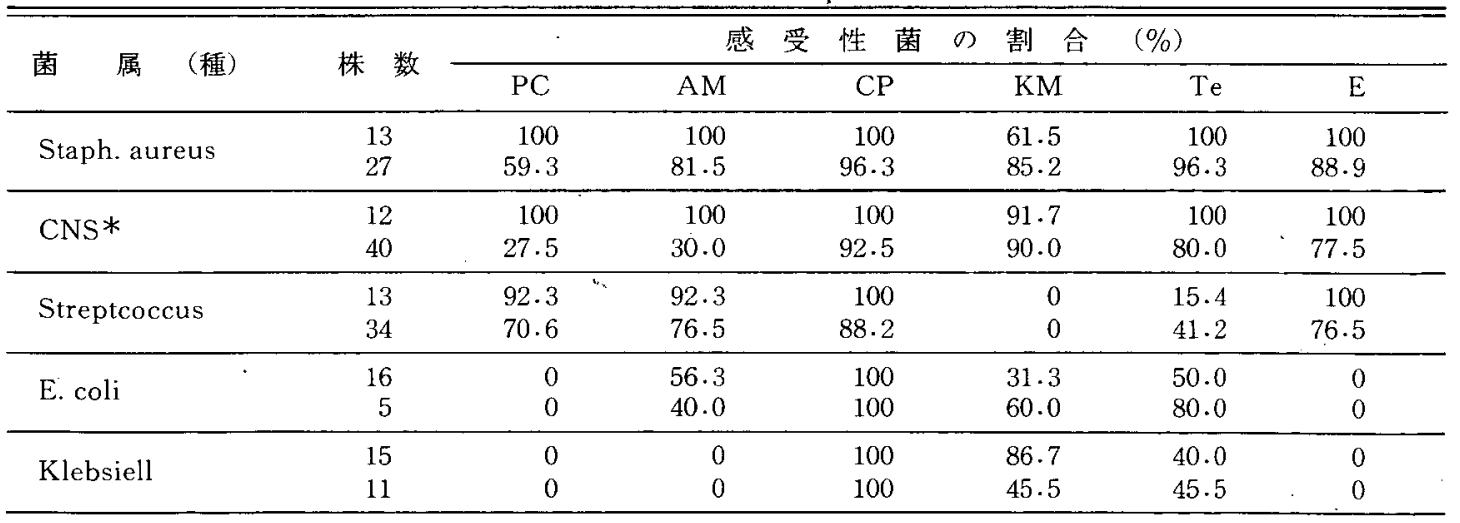

上段：甚急性・急性例

下段：慢性例

* CNS : コアグラーゼ陰性ブドウ球菌
PC :ペニシリン

$\mathrm{AM} ：$ アンピシリン

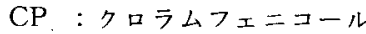

$\mathrm{KM}$ : カナマイシン

$\mathrm{Te}$ : テトラサイクリン

$\mathrm{E} \quad$ : エリスロマイシン 
表 4 . 甚急性・急性乳房炎牛の臨床症状

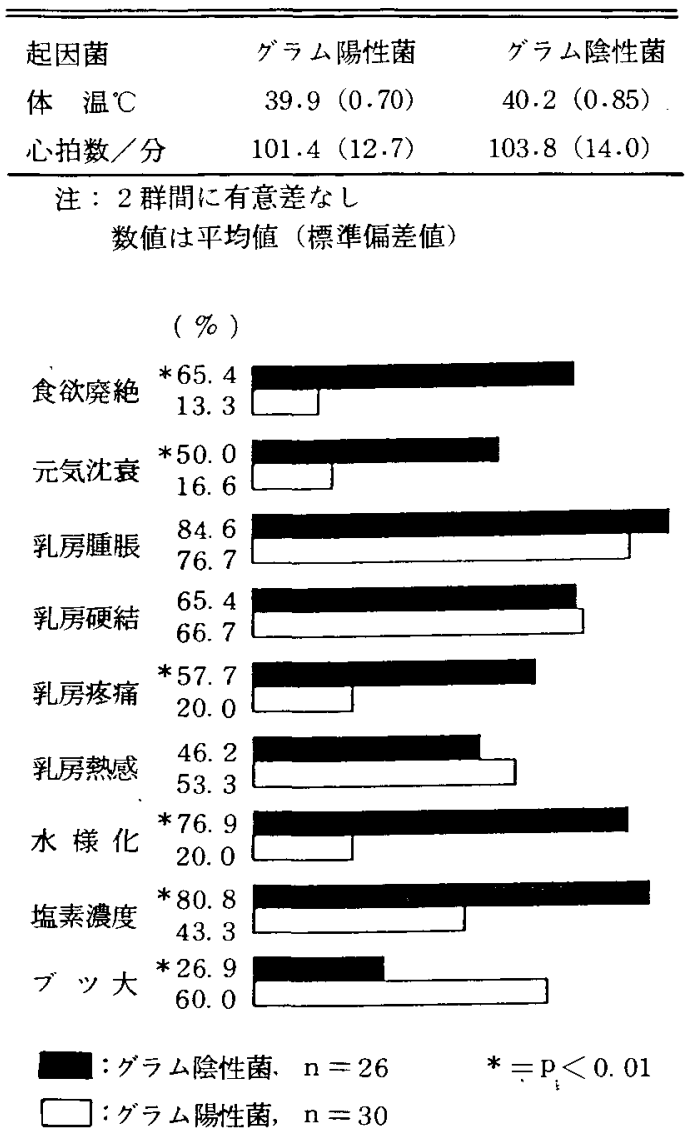

図1.各臨床症状の出現率の比較

\section{考察}

近年、感染症の診断に細菌検查が日常検查として導入 され、それが定着しつつあるが、乳房炎の起因囷に関す る薬剂感受性についても数多く報告されるようになった。 しかし、起因菌の薬剤感受性を病型别に取り扱った報告 はほとんどみられない。今回の調査成績では、グラム陽 性菌による甚急性・急性乳房炎では PC 耐性菌がほとん ど認められなかった(38株中 1 株)が、慢性症のそれ(101 株中48株）との間には著しい違いが認められた。このこ とはまた、今回調查した甚急性・急性乳房炎牛のほとん どが過去に乳房炎歴を有せず、かつ乳房炎の発症が各牛 群の中で散発的であったことなどを考慮す机ば、今回の 症例の多くは牛の体表および環境中に存在する薬剤感受 性の常在菌により発症したものと考えられる。

一方、慢性乳房炎由来菌、特にCNS では多くの抗生 物質に耐性が認められたが、これらの乳房炎牛は過去に 抗生物質の投与が反復されたものであり、それが而性化

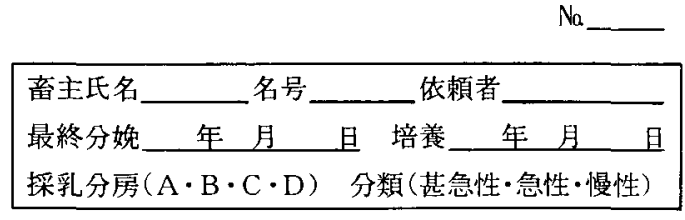

初診時の症状

・発症までの時間経過（笑発・1 日・2 日）

- 全身症状 $\mathrm{T}(\mathrm{N}), \mathrm{P}(\mathrm{)}, \mathrm{R}(\mathrm{)})$

[食廃・元気消沈・悪寒戦慄 -

四視耳端冷感・意識障害

- 局所症状（腫脹・疼痛・硬結・熱感 -

- 乳量 (無乳・激減・正)

- 乳汁 PLT $\mathrm{pH}$ 凝集

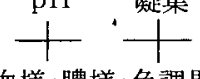

[水様・血様・膿様・色調異常・塩素濃度（） ブッ大・ブッ小

- 併病等 (乳損 - 乳漏 - 胎停 - 起不 -下痢

- その他(

依賴者の診断 〔g (+)・g (-) ]

その根攵

図 2 ．乳房炎細菌検查依頼カード

に結びついたものと考えら机る。S. aureusよりもCNS で而性菌が多いのは、前者が注入薬剤の到達しにくい小 葉間組織や乳腺胞内に定着寸るのに対し、後者は乳腺組 織人の真の病原性が低いため注入薬唎との接触機会が多 いことに誘発されたものと考えられる。Streptcoccus の $\mathrm{KM}$ に対する感受性について熊谷ら ${ }^{5)}$ は大部分の株が 耐性であると報告しているが、今回はこれとほぼ一致し た成績であった。グラム陽性菌では、PCの最小発育阻止 濃度が他薬剤と比較して極めて低く4，5，8，101、特に PC 感受性菌に対寸る抗菌活性は、現在でも、最も強力であ る3)といわれている。したがって、甚急性・急性例に対 しては迷わずPC を選択すべきであると考える。グラム 陰性菌の感受性では、これまでの報告 $2,6,7$ とほほ類似 の感受性を認めた。よって、これに対しては現状では、 $\mathrm{CP} 、 \mathrm{KM} 、 \mathrm{AM}$ を選択すべきである。乳房炎の臨床症 状と起因菌との相関性について検索した成績では、グラ 么陽性菌で極めて特徴的な傾向が認められたが、これは 限られた地城、および酪農家における所見であり、これ が他の地域にも応用できるか否かについては、今後さら に多くの地域、および酪農家について検索する必要があ る。他方、本病の効果的な治療・予防対策を立てるため 
には、各地域の実情にあわせた治療指針を樹立寸ること が必要であると考える。

今回、グラム陰性菌による症例で出現率の有意に高い 臨床症状としては、食欲廃絶、元気沈衰、乳房の疼痛、 乳汁の水様化、乳汁塩素濃度上䄯の 5 項目であったが、 これらの所見は他の報告 $\left.{ }^{9}, 11 ， 12\right)$ とほぼ一致した成績で あった。Andersonら11らは、エンドトキシンを乳房に 注入することにより、食欲の低下廃絶、沈うつ、乳房疼 痛、乳房水腫、および乳汁の漿液化等の発現することを 観察している。したがって、著者らが認めた両群におけ る臨床症状の違いの主な原因は、グラム陰性菌のエンド トキシンに誘発された病徴とも考えられる。今回、高率 に観察された乳房腫脹、疼痛および乳汁の水様化、塩素 濃度上昇等の所見は、エンドトキシンによる細胞障害と 血管作動性物質に誘発された血管透過性の異常な穴進 ${ }^{3)}$ を反映したものであり、重篤な全身症状はショック状態 がすでに hypodynamic state ${ }^{3)}$ に移行していることを 示唆している。したがって、今後は、ショック状態が hyperdynamic state $力 5$ hypodynamic state 一移行 した際にみられる全身の徝環系の虚脱を反映する四肢泠 感、乏尿、脈性状の変化（頻数微弱）等についても観察 し、さらにその診断精度を高めたいと考える。

\section{文献}

1) Anderson, K. L., Smith, A. R., Shanks, R. D., Davis, L. E., Gustafsson, B.K. (1986). Efficacy of flunixin meglumine for the treatment of endotoxininduced bovine mastitis. Am. J. Vet. Res., $47,1336 \sim 1372$.
2 ）安里 章 (1986).臨床現場における乳房炎の微生物 学的検查：臨床獣医， 4 : 58 62.

3) 船田 久 (1986).敗血症とその周辺疾患, 第 1 版, $70 \sim 115$, 新興医学出版社, 東京.

4) Herry Sincoweay - 宮地龍彦・柏畸 守・年米常 夫（1980）。乳汁由来コアグラーゼ陰性ブドウ球菌の 薬阂感受性. 日本兽畜大研究報告, $29,58 \sim 62$.

5 ）熊谷信一・磯部 尚・久米常夫・生方公子・紺野昌 俊・嵄峨井均・志村武雄 (1981).牛の乳房炎乳汁由 来レンサ球菌の分類と薬剤感受性. 家畜衛試研究報 告, $81,1 \sim 7$

6) McDonard, T. J., McDonard, J. S. and Rose, D. L. (1970). Antimicrobial sensitivity of aerobic Gram-Negative rods isolated from bovine udder infections. Am. J. Vet. Res., 31, 1937 1941 .

7 ) 野村 武 (1986).グラム陰性菌による牛の甚急性乳 房炎の実態とその治療. 家畜診療, $282,21 \sim 40$.

8 ）小川美敬・遠藤俊夫（1988）.牛の乳汁由来コアグラ 一ゼ陰性ブドウ球菌の分類と薬剤感受性。日獣会誌, $41,40 \sim 44$.

9) 田幡欣也・鈴木洋三・佐々木孔平・増田悦郎・増山 昭秀・山本展司・山口博江・楠瀬和子（1988）・グ ラ ム陰性菌による乳房资の早期診断のために一初診時 の臨床症状についての解析一。家畜診療, 299，47 53.

10）植手鉄男 (1986). 抗生物質 選択と臨床の実際. 改 訂 5 版， 68〜 179, 医薬ジャ一十ル社, 東京.

11) White, M. E., Glickman, L. T., Montgomery, M. E., Barnes-Pallesen, F. D. (1987). Analysis of the clinical findings used to diagnose coliform mastitisin dairy cows, and comparison to a prediction model. Cornell Vet., 77, 13 20.

12) White, M. E. and Montgomery, M. E. (1987). The Resemblance of Clinical Attributes Between MastiticCows with No Growth on Bacterial Milk Culturesand those with Gram-positive Bacteria Cultured. Can. J. Vet. Res., 51,181 184. 